\title{
Orientalizing New Spain: Perspectives on Asian Influence in Colonial Mexico ${ }^{1}$
}

DOI: $10.32870 /$ mycp.v15i43.380

Edward R. Slack, Jr. ${ }^{2}$

\section{Resumen}

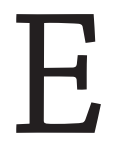
ste artículo investiga la totalidad de la influencia de Asia sobre la Nueva España que resultó de la conquista de Manila en 1571 y la regularización del comercio Transpacífico-comúnmente conocido como los galeones de Manila o las naos de China- entre las Filipinas y Acapulco. En sus inicios, una oleada constante de inmigrantes asiáticos, mercancías y nuevas técnicas de producción influyeron mesuradamente en la sociedad y la economía colonial mediante un proceso que el autor denomina "Orientalización". No obstante, en ninguna manera "Orientalización" se debe equiparar con el concepto de Edward Said de "Orientalismo" por la relación histórica, única e intima de la Nueva España con Asia a principios de la edad Moderna.

\section{Abstract}

This article examines the totality of Asia's influence on New Spain that resulted from the conquest of Manila in 1571 and the regularization of transpacific trade-more widely known as the Manila Galleons or naos de China-between the Philippines and Acapulco. In its wake, a steady stream of Asian immigrants, commodities, and manufacturing techniques measurably impacted colonial society and economy through a process the author calls "Orientalization." However, "Orientalization" should in no way be equated with Edward Said's

1. Artículo recibido el 28 de octubre de 2011 y dictaminado el 16 de noviembre de 2011.

2. Eastern Washington University. 
concept of "Orientalism" because of New Spain's uniquely intimate historical relationship with Asia in the early Modern era.

\section{Introduction}

Contrary to popular belief, the Philippines Islands were more a colony of New Spain (Nueva España) than of "Old Spain" prior to the nineteenth century. The Manila galleons, or naos de China (China ships), transported Asian products and peoples to Acapulco and other Mexican ports for approximately 250 years. Riding this 'first wave'

Riding this 'first wave' of maritime contact between the Americas and Asia were travelers from China, Japan, the Philippines, various kingdoms in Southeast Asia and India known collectively in New Spain as chinos (Chinese) or indios chinos (Chinese Indians), as the word chino/a became synonymous with the Orient of maritime contact between the Americas and Asia were travelers from China, Japan, the Philippines, various kingdoms in Southeast Asia and India known collectively in New Spain as chinos (Chinese) or indios chinos (Chinese Indians), as the word chino/a became synonymous with the Orient. The rather indiscriminate categorizing of everything "Asian" under the Spanish noun for the Ming/Qing empire, its subjects and export items is easily discovered in a variety of sources from that age. To illustrate, the eighteenth century works of

Italian adventurer Gamelli Carreri and the criollo priest Joachin Antonio de Basarás (who evangelized in Luzon) nonchalantly refer to the Philippine Islands as "la China." Additionally, words such as chinería (Chinese-esque, European/Mexican imitation of Chinese wares), chinero (a cupboard or cabinet for chinaware), and achinado/a (Oriental-looking) are a distant echo from this

3. Gemelli Carreri, Viaje a la Nueva España (Mexico City: Biblioteca Minima Mexicana, 1927), 1:26-27, 30-31 (Carerri visited New Spain in 1697 via the Manila galleon); Joachin Antonio de Basarás, Origen, custumbres y estado presente de mexicanos y philipinos, descripción acompañada de los estampas en colores (Mexico City: n.p., 1763), 1:23, 185. 
lengthy - but mostly forgotten - period of cultural and economic exchange across the Pacific Ocean.

This article examines the overlooked process of Orientalization that took place in the viceroyalty of New Spain from 1565 until 1815, dates that represent the first successful transpacific voyage from the Philippines to colonial Mexico and the last "China ship" to depart Acapulco for Manila, respectively. It would be a truly Quixotic undertaking to analyze the totality of Asia's influence on New Spain within the scope of this brief study. That having been said, I nevertheless do believe that certain long-term trends and tendencies can be explored at both the micro and macro levels from the following perspectives: Asian migration and cultural assimilation strategies; the conspicuous consumption of Oriental products and their socio-cultural impact; and the significance of the Manila-Acapulco commerce on Mexico's domestic economy.

\section{Asian Migration and Cultural Assimilation: The Importance of the Chino Network}

Spanish galleons transported Oriental goods and travelers from Manila to colonial Mexico primarily through the port of Acapulco. During the two and one-half centuries of contact between the Philippines and the viceroyalty of New Spain, a minimum of 40,000 to 60,000 Asian immigrants would set foot in the "City of Kings" (Acapulco) while a figure double that amount $(100,000)$ would be within the bounds of probability. ${ }^{4}$ From Acapulco they would gradually disperse to the far corners of the viceroyalty. The majority, however, would eventually settle in two distinct zones: on the west coast in the districts of Guerrero, Jalisco, and Michoacán; and in the large, ethnically diverse municipalities of Mexico City and Puebla in the central valleys, and the eastern port of Veracruz.

Along the Pacific coast, chino sojourners tended to congregate in the cities and pueblos of Acapulco, Coyuca, San Miguel, Zacatula, Texpan, Zihuatenejo, Atoya, Navidad, Guadalajara, and Colima. With the arrival of more ships

4. There are a few estimates for Asian immigrants to Mexico during the colonial era. See Fernando Benítez, ed., El Galeón del Pacífico: Acapulco-Manila, 1565-1815 (Mexico City: Biblioteca del Sur, 1992), 38; Floro L. Mercene, "Filipinos in the New World," Manila Bulletin (18-20 June, 2000) http://filipinokastila.tripod.com/FilMex.html, 2-6; and Jonathan Israel, Race, Class, and Politics in Colonial Mexico, 1610-1670 (Oxford University Press, 1975), 75-76. 
from Manila, the number of sailors and merchants who either had no desire to return to the Philippines or others brought over as slaves and servants married local Indian and mixed-race women. Consequently, a sizable population of chinos and their descendants made these cities and pueblos a popular destination for fellow Asians. Both freemen and slaves farmed rice (brought from the Philippines), corn, cotton, tobacco, and tended cacao and coconut palm trees, fished in the seas and rivers, and transported people and goods to various ports along the coastline. Those who followed the royal highways to towns farther inland worked in the silver mines, haciendas, obrajes (textile workshops), or sugar mills. ${ }^{5}$

The highest densities of urban Asian immigrants were located in Mexico City, Puebla, and Veracruz. Mexico City, colonial capital and the crossroads between Europe, Africa, the Americas and Asia, provided the most favorable economic opportunities for chinos in the viceroyalty. A small sampling of the diverse occupations listed for Oriental transplants includes harp players, dancers, scribes, tailors, cobblers, butchers, silversmiths, embroiderers, and coachmen. The most prominent vocations were barbers and venders of various goods, such as cotton and silk textiles from Asia, Mexico and Spain/Europe, comestibles (including aguardiente, molasses, chickens, confectionaries, sugar and cacao), or second-hand items. ${ }^{6}$

In the Plaza Mayor (known today as the Zócalo), the mercantile heart of the Spanish empire, an outdoor marketplace of stalls and small shops called the Parian (named after the first "Chinatown" of the modern era established in Manila) satisfied the exotic demands of elites and commoners alike. Asian venders, craftsmen, barbers, and those with marketable skills successfully competed with Iberian, African, Indian, and mixed-race groups to eke out a living in a strange, new land, surmounting formidable linguistic and other

5. Archivo General de la Nación, Mexico City (henceforth AGN) Grupo 110, vol. 3624, cuaderno 6 (11/10/1757); Francisco de Solano, ed., Relaciones Geograficás del Arzobispado de México, 1743 (Madrid: Centro de Estudios Históricos, 1988), 1:25-26; 63-65; 2: 299-300, 467-474; Nicole von Germeten, Black Blood Brothers: Confraternities and Social Mobility for Afro-Mexicans (Gainesville: University Press of Florida, 2006), 158-163, 170.

6. AGN Grupo 58 vol. 10, ex. 249, f. 142 (1630); vol. 21, ex. 220, f. 192 (1657); vol. 24, ex. 85, f. 48v-49r (1665); Grupo 61 vol. 999, ex. 6, f. 335-336 (1750); v. 1169, f. 263 (1719); Grupo 69 vol. 46, ex. 53, f. 277-80 (1699); vol. 47, ex. 57, f. 162-165 (1745); vol. 93, ex. 111, f. 296-297 (1612); v. 100, ex. 31, f. 163-166 (1744); v. 113, ex. 135, f. 345-346 (1629); vol. 118, ex. 106, f. 277-29 (1717); vol. 139, ex. 38, f. 4 (1663); v. 183, ex. 80, f. 2 (1637); Grupo 100 vol. 35, ex. 254, f. 233 (1644). 
cultural challenges. For example, in 1632 a license was granted to Juan Salvador allowing him to sell used iron goods from a small table in the Plaza Mayor. ${ }^{7}$ It is also noteworthy that a number of government licenses sold to chino merchants contained a common address - the barrio of San Juan. It was a marketplace near the Calle of San Agustín, where weavers, tailors, and textile merchants lived and plied their trades in the capital; a compatible environment for Asians who sold silk and other fabrics transported from Manila. ${ }^{8}$ One could therefore theorize that San Juan acted somewhat as the prototype "Chinese" barrio of the Americas in the seventeenth century. In any event, following the 1692 Mexico City riot, Asian venders began to lodge inside of a single building in the Plaza Mayor. The guild of chino merchants petitioned the viceroy Duque de Linares to officially name this edifice "El Parián," and after 1712 it received government approval to sell the wares that annually arrived from the Philippines under that name. ${ }^{9}$

Puebla de Los Angeles, a city renowned for its industrial production of textiles, pottery, porcelain and glassware, was another significant reservoir of Asian immigrants pouring into New Spain from Manila. An additional link between Puebla and the Manila galleons was the flour trade and numerous bakeries that provided the most essential victual for crewmen, friars, merchants and administrators setting sail for the Philippines: bizcochos (ship biscuits). ${ }^{10}$ The "City of Angels" was connected to Mexico City and the Atlantic port of Veracruz by a royal highway. Chino freemen and slaves were an important cog in its economic machinery. Workers in various trades were divided into guilds or gremios that had master/apprentice hierarchies jealously guarded by Iberian colonists. In 1676, Antonio Gonzales de Velasco, Emmanuel Felipe de Sanda, and Melchor de Ortega, the Spanish officers and overseers of the guild of pañeros (weavers of tapestries, drapes, and other textiles) in Puebla,

7. AGN Grupo 51 vol. 7, ex. 221, f. 147 (15 June 1632).

8. See AGN Grupo 58, vol 19, ex. 172, f. $90-91$ (10 July 1651); vol. 19, ex. 336, f. 190 (January 1661); vol. 20, ex. 63, f. 38 (11 March 1656); v. 24, ex. 85, f. 48-49 (12 July 1665); Ronald J. Morgan, Spanish American Saints and the Rhetoric of Identity, 1600-1810 (Tucson: University of Arizon Press, 2002), 161.

9. Teresa Castelló Yturbide and Marita Martínez del Río de Redo, Biombos Mexicanos (Mexico City: Instituto Nacional de Antropologia e Historia, 1970), 13.

10. Alexander von Humboldt laments the decline of this trade in Puebla by the last decades of the eighteenth century. See Alexander de Humboldt, Political Essay on the Kingdom of New Spain, translated by John Black (London: Longman, Hurst, Rees, Orme, and Brown, PaternosterRow, 1811), 2:199. 
submitted a new set of organizational regulations to the cabildo (municipal council) that stipulated it "will not admit for consideration in the posts of overseers or officers of this gremio any negro, mulato, or chino slave, even if he is a freeman." In its infinite wisdom, the municipal council did not agree with this anti-casta proviso, stating that "any person of any qualities or condition" should be allowed to serve in positions of authority. ${ }^{11}$ Undoubtedly, skilled chino embroiderers and weavers were employed in Puebla and other centers of textile production in New Spain, sharing their techniques with local indios and various castas employed therein.

\section{Domingo de Villalobos: A Pampangan Arriero in Tzapotlán}

The overwhelming majority of chino immigrants who settled in New Spain can be distilled down into four distinct racial categories: native Filipinos, Christian Chinese and their mestizo offspring from the Philippines, Japanese, and those from Mughal India. Unquestionably, the most populous group among these four was a diversity of tribal peoples from the Philippine Islands, more specifically from the island of Luzon. Tagals and Pampangans as a plurality represented the chino demographic owing to their proximity to the colonial capital of Manila and service to Spanish secular and religious authorities. A court case from 1757 in the barrio of San Nicolas Obispo, near Coyuca, clearly illustrates the phenomenon. The document states "[f]rom ancient times the Philippine Indians who came from Manila in the annual galleon" would lodge in San Nicolas Obispo because it was conveniently located not too distant from Acapulco for the return voyage. ${ }^{12}$ Many of them remained behind and married native indias, and over the span of two centuries years grew into a large community administered by the church. They planted rice, corn, cotton, harvested fruit, and cut wood on the lands owned by the Convent of the Conception, paying 50 pesos a year in rent for this privilege. It is also disclosed how Filipinos built canoes which they used for fishing and also to transport travelers across the Coyuca River that emptied into the Pacific Ocean. ${ }^{13}$

11. AGN Grupo 82 vol. 6, ex. 39, f. 45-52 (19 November 1676). Italics added by the author. The term calidades [qualities] has multiple definitions, including race, occupation, slave or free status, wealth and reputation.

12. AGN Grupo 110 vol. 3624, cuaderno 6, (11/10/1757).

13. Ibid. 
Although the bulk of existing sources provide only tantalizing glimpses of their lives in colonial Mexico, it is possible to reconstruct a fairly clear picture of one of these Filipino immigrants who settled on the Pacific coast from a court case pertaining his estate. Domingo de Villalobos was a chino from Pampanga, who died in 1618 at the age of 31 . He was an arriero (muleteer) who owned nine mules and earned a good living from transporting Asian commodities from Acapulco to Mexico City, Colima, and Guadalajara. ${ }^{14}$ All economic activity in New Spain was dependent upon the arrieros and their beasts of burden, since the rocky terrain and primitive condition of the roads made cart or carriage traffic impracticable in many regions. Alexander von Humboldt recorded that "[t]housands of mules arriving every week from Chihuahua and Durango to Mexico [City], carry besides bars of silver, hides, tallow, some wine of Passo del Norte, and flour; and they take in return woolen cloth of the manufacture of Puebla and Queretaro, goods from Europe, and the Philippines Islands, iron, steel, and mercury."15 Without a doubt muleteers were the overworked heart pumping the lifeblood of specie, merchandise, and nourishment throughout the entire body of the viceroyalty.

Domingo de Villalobos lived in the scenic pueblo of Tzapotlán (today San Cristóbal) situated on Lake Chapala, about 60 kilometers to the southwest of Guadalajara as the Quetzal bird flies. It was described as a pueblo of indios with nary a Spaniard amongst them. His closest circle of friends included other Filipinos who resided in Tzapotlán, the nearby pueblo of San José, and Acapulco. Villalobos lived in the house of his best friend, the indio chino Alonzo Gutierrez, whom he appointed executor of his will and entrusted to send 100 pesos to his mother Monica Binanpan in Pampanga after his death. The will also revealed the names of other chinos in Tzapotlán who served as witnesses or inherited portions of his estate: Francisco Luis, Nicolas Malanquil, Juan Triana, and Francisco Matthias. Living in San José and Acapulco were the chinos Andrés Malate and Agustín Pampanga (who kept his padlocked cashbox), respectively. ${ }^{16}$

Based on the information provided in this document, it is apparent that fellow Pampangans or Filipinos whom Domingo Villalobos befriended

14. Archivo General de Indias, Seville (henceforth AGI) Contratacion 520, N. 2, R. 14 (16211622).

15. von Humboldt, Political Essay on the Kingdom of New Spain, 4:14.

16. AGI Contratacion 520, N. 2, R. 14 (1621-22). 
spoke his native tongue and facilitated his acculturation in New Spain. This 'chino network' was a vital cultural key that helped unlock the mysteries of colonial Mexican society, while at the same time provided Asian immigrants psychological and emotional support through tangible links with their own language, customs and family members back in the Philippines. ${ }^{17}$ It is not stated whether Domingo spoke the Spanish language "tan ladino" (very fluently) or "bozal" (poorly with a thick native accent), nor how long he lived in New Spain. Regardless, the fact that he primarily associated with fellow Filipinos in his personal and business life facilitated his acculturation to New Spain.

Other facets of his life gleaned from this document are equally important. For instance, Domingo Villalobos owned an arquebus and pocket pistol, a Castilian-style sword, dagger, girdle and belt, in addition to a Japanese kata$n a$ (sword). ${ }^{18}$ Pampangans served as auxiliaries to the Spanish troops in the Philippines since the earliest days of conquest. Thus it is logical to conclude that Domingo Villalobos used his military experience as a springboard to New Spain. Although he wasn't married, Domingo Villalobos had a comadre (lady friend) named Catalina la Mujer de Bautista to whom he willed a female mule with saddle "because she must be careful [traveling] on Sundays and fiestas." ${ }^{19}$ He also had a servant named Miguel who inherited some coarse cloth. His declared earthy possessions (that were stored in several cities along the coast) reveal the significance of the Asian trade in New Spain: Chinese textiles included 49 Nankeens, 8 pieces of taffeta, one piece of Damask, 32 pairs of cotton medias, glossy silk trousers, 5 sinavafas, and 16 cotton girdles; plus a pair of garters and embroidered sash from Japan. Other valuable items (outside of his mules) included cinnamon, Chinese white wax, salt, cacao, and Mexican cloth. All of the properties sold by his chino friend/executor to cover Domingo's earthly debts amounted to 876 pesos 5 reales. ${ }^{20}$ Based on the possessions and capital enumerated in his will, it would be fair to say that Domingo Villalobos lived a reasonably comfortable existence in the New World.

17. I would like to thank Adam Mckeown and his book Chinese Migrant Networks and Cultural Change: Peru, Chicago, Hawaii, 1900-1936 (Chicago: University of Chicago Press, 2001) for the conceptual framework of what I term the 'chino network'.

18. AGI Contratacíon 520, N. 2, R. 14 (1621-22).

19. Ibid. Catalina la Mujer de Bautista was most likely an india.

20. Ibid. 
Religious cofradias (confraternities) were a significant driver in the process of acculturation for Asian immigrants. Confraternities ensured members a decent Christian burial with the accompanying liturgies at the time of one's death, and established hospitals to care for slaves and freemen of the lower castes. ${ }^{21}$ Nicole von Germeten's pioneering work on colonial "Afromexican" confraternities examined how those with African blood "created fictive families for themselves by joining confraternities," which in turn "provided social connections, charity, and status for their members within towns throughout New Spain."22 In colonial Mexico, chino-only confraternities or those with a mixed demographic membership that included Asians were quite widespread. Gemelli Carreri's chronicling of a "procession of the Chinese" that he witnessed in Mexico City during the celebration of Easter in April 1697 was the chino Confraternity of Holy Christ, affiliated with the Santa Catalina monastery. Founded by Asians around the mid-seventeenth century, in 1692 the confraternity was granted approval to construct a small chapel to the Virgin Mary that was decorated with ivory statuary imported from Manila. ${ }^{23}$

Thus it is not surprising that confraternities were a vital cobblestone on the spiritual 'Road to Damascus' walked by Domingo de Villalobos in New Spain. With such a large population of chinos in Mexico City, the "chino network" certainly included a confraternity that provided invaluable assistance on many levels while Villalobos was doing business in the capital. His last will and testament instructed Alonzo Gutierrez to deliver four male mules to the majordomo of the Confraternity of the Souls in Purgatory (Cofradía de los Ánimas de purgatorío) in Mexico City, an act that literally documents the significance of these religious groups to the process of cultural assimilation. ${ }^{24}$

21. von Germeten, Black Blood Brothers, i, 82 .

22. Ibid.

23. Gemelli Carreri, Viaje a la Nueva España (Mexico City: Biblioteca Minima Mexicana, 1927), 1:102-103; Gauvin Alexander Bailey, "Asia in the Arts of Colonial Latin America," in Joseph J. Rashel with Suzanne Stratton-Pruitt, eds., The Arts in Latin America, 1492-1820 (New Haven: Yale University Press, 2006), 61; Virginia Armella de Aspe, "Artes Asiáticas y Novohispanas" in Fernando Benítez, et al., El Galeón del Pacífica: Acapulco-Manila 1565-1815 (Mexico City: Biblioteca del Sur, 1992), 222; von Germeten, Black Blood Brothers, 101. Known as the "Poor Clares," this female branch of Franciscans established a monastery in Manila around 1921. The actual name of the confraternity was Archocofradía y Hermandad del Santo Cristo. These chinos washed clothes for the monastery, according to the altar's dedication inscription.

24. AGI Contratacion 520, N. 2, R. 14. 


\section{The Conspicuous Consumption of Asian Commodities and their Cultural Impact}

The inhabitants of New Spain were well known for their conspicuous consumption of an unimaginable diversity of Oriental riches brought to their shores by the Manila galleons. Rich fabrics of silk and velvet, fine porcelains and ivory wares, lacquered furniture, exotic spices and jewelry - all and sundry were embraced with an insatiable fervor. The superabundance of silver unearthed from the seemingly endless mines of New Spain created an unprecedented demand for luxury items, which in turn fostered a social compulsion for the ostentatious display of one's wealth and status in public. More than anywhere else in the viceroyalty, Mexico City was the stage where this elite drama of pomp and circumstance was played out on a daily basis. As William Schurz pointed out in his epic study of the Manila galleon, "All classes, from the Indians of the towns in the torrid lowlands, whom Spanish-made conventions and laws compelled them to wear clothing, to the pampered creoles of the capital, went dressed in the fabrics of the Far East, the cottons of Luzon or India and the silks of China... The bulk of the Chinese silks were consumed by the peninsular and colonial Spaniards and the better-to-do mestizos of Mexico City, though the larger provincial towns like Guadalajara and Puebla also took a share of them." ${ }^{25}$ Every corner of New Spain was in some manner materially affected by the Oriental products transported to Acapulco aboard the naos de China.

\section{Elite Pageantry in Mexico City and its Lustrous Link to Asia}

Mexico City was more than the sum of its parts. Politically, it was the capital of New Spain where the viceroy and his high-ranking administrators passed laws and enforced justice in the realm. In spiritual matters, it was the seat of the Archbishop and his ecclesiastical bureaucracy. Economically, it was the center of commercial activity that acted as an irresistible magnet for a plethora of goods from New Spain, the Americas, Europe, Asia and Africa - not to mention the highly capitalized merchants and skilled craftsmen of numerous trades - whose silver flowed across the Atlantic and Pacific oceans to the remotest parts of the globe. Architecturally, reflected in its palaces, buildings,

25. Schurz, The Manila Galleon, 362. 
cathedrals, streets, parks, walls and aquaduct were the power and prestige of its grandeur. Socially and culturally, it set the standards for etiquette and attire in the Iberian-controlled New World. This concentration of all facets of human activity in Mexico City created a transcendental physical space whose influence radiated far beyond its city walls to the rest of the world.

Accordingly, the social conventions attached to this space by the Mexican nobility created a symbolic "culture of appearances" that reverberated throughout the viceroyalty. Official titles, notions of honor, "purity of blood", social standing, and the number of slaves or servants one possessed were physically attached to the objects that a person wore, owned, or showcased in their household or in public - whether at a fiesta, an intimate social engagement, the parade of carriages, or going to church - "all were part and parcel of the sumptuous display that corresponded to one's visual image in society." ${ }^{26}$ The pageantry of aristocratic life exemplified in the exotic Oriental objects transported from Manila was a means to project its social superiority onto both itself and lower classes, as was evident in words of Thomas Gage, Bernardo de Balbuena, and others who chronicled the material gluttony of human existence in Mexico City during the seventeenth and eighteenth centuries. An examination of various luxury goods unloaded in Acapulco and how they were utilized by elites (for profit and/or display) underscores how important Oriental products were to the lavishly decadent elite theatre acted out in Mexico City during this era.

Certainly the most flagrant manifestation of Asian extravagance were the multitude of fabrics available to elites - and their tailors - with which to cut, sew, stitch, dye, hem, embroider, garnish, and embellish the bodies of high society bon vivants in the capital. In addition to a dazzling array of silks, satins, and damasks, the Middle Kingdom also produced a rainbow of colored cottons and linens sometimes referred to as mantas (plain cottons) or elefantes (elephant stuffs), in addition to the more exotic sounding sayasayas (a type of silk sarong) for women and silk kimonos (quimonos) that were cut into three-piece suits for gentlemen and chasubles for clerics. ${ }^{27}$ Coming from

26. Frédérique Langue, "De la Munificencia a la ostentación: La nobleza de la ciudad de México y la cultura de la apariencia (siglos XVII-XVIII)" Nuevo Mundo Mundos Nuevos (2/14/ 2005):1-7, http://nuevomundo.revues.org/document642.html, 1-7 (accessed 5 June 2006).

27. AGN Grupo 42 vol. 18, ex. 7, f. 442-448 (4/7/1807); Carmen Yuste, "Los precios de las mercancías Asiáticas en el siglo XVIII" in Virginia García Acosta, ed. Los precios de alimento y manufacturas novohispanos (Mexico City: Instituto de Investigacioes Históricas, 1995), 235, 247. 
India was an equally resplendent spectrum of textiles, including cambayas (cotton fabric from Bengal, Madras, or the Coromandel Coast), gauzes, silks from Bengal, taffetas from Aliabat, chints from Patna, muslins and ginghams, and a host of other fabrics, either painted with barbarian images, embroidered or bordered with gold and silver thread, dyed in flower patterns - and with names such as Baglepur, Sarguilla and Sinsaca that have no meaning hundreds of years later. ${ }^{28}$ Many of the textile items revealed in their names a corruption of their Oriental pedigree. The word paliacate, for instance, a type of colored headscarf popular with women in New Spain, is derived from Calicut (Calcutta) which morphed in palicut somewhere en route to Acapulco; while another fabric called the sangaleto was a corruption of the word Sangley from the Philippines. ${ }^{29}$ Even the buttons of silk, copper, and crystal on various articles of clothing were abundantly available for a reasonable price. ${ }^{30}$

An essential article of clothing for both sexes, adults and children, was the silk and cotton stockings or doublets (medias) from China, primarily via the ports of Canton and Quanzhou. ${ }^{31}$ When discussing the Oriental trade at Acapulco in the 1740s, the pirate George Anson mentioned that in addition to spices, "all sorts of Chinese silks and manufactures; particularly silk stockings, of which I have heard that no less than fifty thousand $(50,000)$ pair were the usual number shipped on board the annual ship; vast quantities of Indian stuffs, as calicoes and chintz, which are much worn in America, together with other minuter articles, as goldsmiths works, \&c. which is principally done at the city of Manila by the Chinese; for it is said there are at least twenty thousand Chinese who constantly reside there, either as servants, manufacturers, or brokers. All these different commodities are collected at Manila, thence to be transported annually in one or more ships, to the port of Acapulco, in the Kingdom of Mexico." 32

28. AGN Grupo 42 vol. 18, ex. 7, f. 442-448 (4/7/1808).

29. Eva Alexandra Uchmany, "Encounters between New Spain and the Indian Subcontinent during the Colonial Period" in Eva Alexandra Uchmany, ed., India-Mexico: Similarities and Encounters Throughout History (New Delhi: Indian Council for Cultural Relations, 2003), 91; José Benitez, El Traje y el Adorno en México, 1500-1900 (Guadalajara: Imprenta Universitaria, 1946), 138.

30. Yuste, "Los precios de las mercancías Asiáticas", 236, 241.

31. Ibid., 245.

32. George Anson, A Voyage Round the World in the Years MDCCXL,I,II,III,IV, edited by Glyndwr Williams (London: Oxford University Press), 219. 
Fans or abanicos were another Asian import desired by elite women of the viceroyalty. Originally introduced to Europe from China by Jesuit missionaries during the regency of Catherine de Medici (1560-1589), abanicos were considered an essential female accessory. ${ }^{33}$ Painted scenes of Asian landscapes or exotic themes on paper, with ribs of ivory, lacquered wood or sandalwood, imported fans were regularly on the manifests of the naos de China. ${ }^{34}$ According to Gustavo Curiel, "The incessant fluttering of expensive fans was as much for the benefit of observers as it was to alleviate the heat. The fan was the key element of the female visual language, as in the case of Bernarda Laurencia de Torres y Mendiune, one of the vicereine's attendants. In the year 1691, her wardrobe included a total of sixty fans from Spain and China. This is just an isolated example of the great fondness that the ladies of the viceregal court had for fans. With them, they created a secret language, sending coded messages to suitors by leaving fans on the dais, or closing it sharply, or opening it halfway, or striking it against something." ${ }^{35}$ Another piece of chinería that complimented the sumptuous display of elite ladies was the parasol, painted on lacquered paper with similarly exotic scenes. ${ }^{36}$ Fans and parasols were items that Mexican artisans copied and sold widely throughout the viceroyalty.

Luxury items of an astonishing variety were likewise exhibited in rooms throughout the household. The finest were prominently displayed in the salón de estrado. An elegantly female space, it "takes its name from the dais (estrado), which raised a part of the space above the floor level. This platform was generally covered with fine rugs, and scattered with cushions and exquisitely crafted furniture." ${ }^{37}$ Not surprisingly, Persian and Chinese carpets, silk cushions, and oriental furniture embellished the parlor room to accentuate the opulent mark of refinement projected by the lady of the house. Men would also have their own gathering areas, such as the fumador (Smoking Room) that is showcased in the Castle of Chapultepec, known today as the Museo

33. Benitez, El Traje y el Adorno en México, 95-96.

34. Yuste, "Los precios de las mercancías Asiáticas", 241, 253.

35. Gustavo Curiel, "Rituals among the Elites of New Spain: The Evidence from Material Culture" in Héctor Rivero Burrell et al., The Grandeur of Viceregal Mexico: Treasures from the Museo Franz Mayer (Mexico City: Museo Franz Mayer and the Houston Museum of Fine Arts, 2002), 29.

36. AGN Grupo 42, vol. 18, ex. 7, f. 442-448 (4/7/1807); Yuste, "Los precios de los mercancías Asiáticas", 246.

37. Curiel, "Rituals among the Elites of New Spain", 28. 
Nacional de Historia in Mexico City. ${ }^{38}$ The atmosphere is one of Oriental splendor, with fine Asian furniture and large vases providing the ambience for indulging in tobacco and alcoholic refreshments. It was not uncommon in the eighteenth century for billiard tables to be installed for recreational purposes, with ivory billiard balls and brass spittoons imported from China for male socializing rituals. ${ }^{39}$

Other items for household consumption included quilts, bedspreads, bed sheets, canopies and tapestries for the bedrooms; tablecloths, napkins, assorted porcelain ware and tea sets for the dining areas; drapes and curtains for windows; desks and writing paper for libraries. ${ }^{40}$ Attempting to itemize the sheer volume and variety of articles from Asia brings to mind the words of Antonio de Morga, who said "which, did I refer to them all, I would never finish, nor have sufficient paper for it." ${ }^{41}$ In sum, whatever there was a market for in New Spain - either specific to Iberian culture (such as ivory castanets or tassles for the sword hilts of noblemen) or a more universally appreciated item of utility or adornment - was transported to Acapulco for two and one-half centuries and sold inexpensively to all classes that inhabited the viceroyalty. Unquestionably, the trickle-down effect of what was considered fashionable among elites and the profits they accumulated from the maritime trade link to the Philippines contributed greatly to the ubiquitous acceptance of Oriental products in the New World.

\section{Economic Significance of the Manila-Acapulco Trade on New Spain}

Undeniably, the economic and financial impact of the Acapulco Fair was incalculable with respect to New Spain's internal markets. A multitude of

38. The fumador is located on the bottom floor of the Castle/Museum, marked as room number five on the map.

39. Yuste, "Los precios de los mercancías Asiáticas, 241, 253.

40. AGN Grupo 42, vol. 28, ex. 7, f. 442-448 (4/7/1807); Yuste, "Los precios de los mercancías Asiáticas", 241-264.

41. Antonio de Morga, Sucessos de las Islas Filipinas (Mexico City: 1609) translated by E. H. Blair and J. A. Robertson in The History of the Philippine Islands From their discovery by Magellan in 1521 to the beinning of the XVII Century, with descriptions of Japan, China, and adjacent countries, by Dr. Antonio de Morga, Alcalde of Criminal Causes, in the Royal Audiencia of Nueva España, and Counsel for the Holy Office of Inquisition (Cleveland: The Arthur H. Clark Company, 1907), 2:180. 
domestic products benefitted from the yearly upsurge in demand associated with the exposition, while Asian goods left an indelible mark on cultural artifacts manufactured in the viceroyalty. Those more impacted than others were mining, agriculture, iron/steel industries, porcelain and textile manufacturing sectors of the economy, in addition to the lacquer ware and furniture handicrafts. Besides enriching elites - especially the merchants of Mexico City - the commercial bonanza of la feria generated a steady stream of capital independent of the flotista monopolists from the mother country. As Carmen Yuste López has argued, the profits obtained by this group enabled it to develop into the most powerful economic and political force in New Spain, controlling the exchange of foreign commodities in both Veracruz/Jalapa and Acapulco, subordinating provincial merchants through access to credit, and diversifying its portfolio into silver mining, agricultural/livestock, and industrial activities throughout the viceroyalty. ${ }^{42}$

The repercussions of this semi-autonomous reality were well understood by factions on both sides of the Atlantic, resulting in bombastic denunciations and royal decrees from España met by a spirited defense in New Spain. It was analogous to a game of 'whack-a-mole' economics played by merchants of Manila and Mexico City in their "Two Hundred Years' War" with business interests in the mother country. Whenever Andalusan monopolists demanded a prohibition on the tonnage, number of vessels, the types of cargo and inspection thereof shipped to New Spain, the amount of silver exported to Manila, or whom in the Philippines could participate in the trade, the Mexicans (and Peruvians) would artfully find ways to circumvent them. ${ }^{43}$ Each time the state's hammer came down on one particularly offensive or competitively disadvantageous aspect of the trade between Manila and Acapulco, a few more would rear their defiant heads. The continuous battle between Castilian interests and those of Mexico/Philippines gradually evolved into a begrudging modus vivendi that guaranteed a market for Oriental products in New Spain until the time of the Mexican War of Independence (1810-1821).

42. Carmen Yuste López, "El Galeón en la Economía Colonial” in Fernando Benítez,ed. El Galeón del Pacífico: Acapulco-Manila 1565-1815(mexico City: Biblioteca Del Sur, 1992), 111.

43. See Schurz, The Manila Galleon, 154-190, 361-406; Yuste, "El Galeón en la Economía Colonial”, 104-111. The creation of the Royal Philippine Company in 1785 ultimately proved to have been the most effective step taken by Spanish monopolists to curtail the autonomy of New Spain's commercial dealings with Asia. 
The Acapulco Fair was far more than just a clearinghouse for imported Asian wares. It was akin to a world's fair or international exposition that linked the Orient to all of the economic activity in the viceroyalty, functioning as a vital marketplace for innumerable items grown or manufactured domestically from the farthest reaches of colonial society. Iron and steel articles, forged, hammered and molded in New Spain, solidly represented the colony's small but invaluable ferrous metalworking sector among the crafts sold in Acapulco. The dearth of agricultural implements - such as plowshares, hoes, rakes, and sickles - in the small pueblos and haciendas of the west coast guaranteed brisk sales at the Fair. ${ }^{44}$ A chronic shortage of iron goods plagued colonial Mexico throughout her history. The reasons for this were twofold. In order to protect Vizcayan industries in the mother country, the Crown restricted the development of New Spain's ironworking capacity to ensure that bulk iron and steel imports (unfinished and finished goods) had a captive market. Alexander von Humboldt's quantitative analysis of imports from Spain testifies to that effect. ${ }^{45}$ Secondly, despite an abundance of iron ore deposits in the country, they were woefully undeveloped by investors who opted to pursue the more profitable silver mining enterprises instead. ${ }^{46}$

Consequently, tools such as hatchets, axes, machetes, and saws were in high demand in the forested sierras of the Pacific coast. Silver miners, mine owners, and those who provisioned this king of colonial industries found in Acapulco the shovels and pickaxes essential to their lucrative enterprises. Since the prevailing mode of transportation was via horse, mule, or burro, the bits, bridles, spurs, shoes, and other equine accessories formed a glittering display of items showcased in Acapulco. ${ }^{47}$ Additional manufactures that found a hungry market in the Philippines included nails, screws, hammers, padlocks, window frames, and spears. ${ }^{48}$ The blacksmiths of Oaxaca (famous for their swords and cutlery) were responsible for the bulk of iron products

44. Tomás Oteiza Iriarte, Acapulco; La Ciudad de las Naos de Oriente y de las Sirena Modernas (Mexico City: Modernas Editado, 1965), 90.

45. Von Humboldt, A Political Essay on the Kingdom of New Spain, 4:29-36.

46. Marc Simmons and Frank Turley, Southwestern Colonial Ironwork: The Spanish Blacksmithing Tradition (Santa Fe: Sunstone Press, 2008), 14-20.

47. Iriarte, Acapulco, 90-91; Simmons and Turley, Southwestern Colonial Ironwork, 16.

48. Yuste, "El Galeón en la Economica Colonial”, 104. 
sold at the Fair, although Puebla's renowned metal craftsmanship was a wellrepresented competitor. ${ }^{49}$

The problem of undersupply for finished metal products was partially met by the Manila galleon. A legacy of this phenomenon is still visible inside of the Cathedral of Mexico City, which was adorned by finely crafted works manufactured in Macao: the reja de coro [choral grate enclosing the choiry] and the crujia [the sanctuary rails between the pews] leading to the choiry. The reja de coro was designed by the master artisan Nicolas Rodriguez Juarez in 1721, whose schematics were transported aboard the nao de China via Manila, and cast in Macao. The choral grate was manufactured using a variety of metals - iron, bronze, and a bronze/gold amalgam called tumbaga - by the hand of the Chinese "capitan" Quiauló Sangley. The blueprint of Rodriguez was translated into Chinese by an Italian Franciscan friar in Macao, and when completed was larger and more exquisite than ever imagined by the residents of Mexico City. Transported across the Pacific in 125 crates and bundles aboard the ship Nuestra Señora de los Dolores in 1724, the final tally for this work was 46,380 pesos - almost five times more than was originally estimated. Topped by Baroque figures of the crucifixion and other saints, it was considered unsurpassed in its elegance and superior to any counterpart in Europe. ${ }^{50}$ The adjoining crujia was cast in Macao and arrived at the cathedral in 1743 , composed of the same precious metals, with angelic images adorning the top of the railing acting as candlestick holders. ${ }^{51}$

In Juan Grau y Malfalcon's memorial alluded to earlier, the administrator related how copper

is brought from China with so much facility that the best artillery imaginable is cast in Manila, with which they [the Portuguese] supply their forts, the city of Macan [Macao] and other cities of India, and it is taken to Nueva España; for the viceroy, the Marqués de Cerralvo, sent the governor, Don Juan Niño de Tabora, twenty-four thousand pesos, in return for which the latter sent him eighteen large pieces to fortify Acapulco. ${ }^{52}$

49. Iriarte, Acapulco, 91.

50. Manuel Toussaint, La Catedral de Mexico y el Sagrario Metropolitano: Su Historia, Su Tesoro, Su Arte (Mexico City: Editorial Porrua, S.A., 1992), 107-109. The original allocation for the reja de coro was 10,000 pesos, and the overage was covered by merchants, officials, and clergy in Manila.

51. Ibid. The crujia cost 18,000 pesos.

52. Blair and Robertson, The Philippine Islands, 27:80. 
Alexander von Humboldt similarly described during his travels that several cannons protecting Fort San Juan de Ullua in Veracruz were originally cast in Manila. ${ }^{53}$ Besides the larger products mentioned above, smaller items such as copper nails for upholstering chairs, bronze thimbles, sheets of white copper and brass toothpicks were mixed in with the cargoes. ${ }^{54}$ One cannot say that the quantity of finished metal products emanating from Asia was substantial by any metric, but their superior quality and reasonable price filled a demand that was not always met by the Flota Indiana from Cadíz or the expertise of blacksmiths in New Spain.

\section{Silver Mining}

Mercury from China via the Philippines is an undervalued and mostly ignored contribution to New Spain's rich mining history. Mexico, especially in the seventeenth century, entered a period where processing an overabundance of silver ore was plagued by a persistent insufficiency of quicksilver with which to extract the metal. As M. F. Lang acutely noted, "[t]he chief reason for the quicksilver shortage was that the Crown relied on the production of Almadén [the oldest mercury mine in the world, located in Spain], almost all of which was reserved for New Spain and that this mine rarely managed to produce the 5,000 quintals per year required." ${ }^{55}$ Some of the slack in supply was met by the Huancavelica mines in Peru, but fearful of promoting inter-colonial trade between Mexico and Peru and lessening their economic dependency on España (in addition to Castilian unease with even more silver flowing to the Orient aboard the naos de China) royal authorities strictly curtailed Peruvian shipments to Acapulco until late in the seventeenth century. ${ }^{56}$ Spanish exporters thus would remain the primary source of this essential amalgamating element during the colonial era.

Castilian control over its possessions in the Americas notwithstanding, this matter was of such importance to the Crown that in 1591 King Philip II sent a royal decree to Manila governor Gómez Pérez das Mariñas inquiring about deposits on the islands or from China, the amounts available, the costs

53. Von Humboldt, A Political Essay on the Kingdom of New Spain, 4:20.

54. Yuste, "Los precios de las mercancías Asiáticas", 236, 242, 245, 255.

55. M. F. Lang, "New Spain's Mining Depression and the Supply of Quicksilver from Peru 16001700" HAHR 48.4 (November 1968): 633. One quintal equaled approximately 100 pounds.

56. Ibid.,634-641. 
of dispatching it to New Spain, and the quantities that could be sent to Acapulco annually. ${ }^{57}$ In 1605 the viceroy Marqués de Montesclaros responded to another royal decree regarding this matter, and informed his majesty that Chinese mercury was very pure and that an abundance of it could be found in Canton (100,000 quintals at that time). It was shipped to Manila (in small quantities by Sangley merchants) in boxes of lead and copper. He related that 1,000 to 1,500 quintals could be transported to Acapulco annually at the cost of 45 pesos 5 reals per quintal, of equal quality as that brought from the Almadén mine in Spain at almost one-half the cost (96 pesos 4 tomines per quintal for the latter). Montesclaros therefore advised the king of the benefits of securing a steady supply of Canton's mercury. ${ }^{58}$

Exactly how much quicksilver was transported across the Pacific in the seventeenth century is unknown, but it's quality and cheapness were not in doubt, as viceroy Conde de Salvatierra penned in 1645 "it is clean and pure in the first incorporations, and in the subsequent [uses] very fine and good as that brought to these kingdoms from Peru... it will be a great savings and convenience" to order its continued shipment to New Spain. ${ }^{59}$ In 1689 as stocks from the Almadén mine had been depleted, and the Spanish court had been negotiating with the Holy Roman Empire to purchase it from the mine at Idria, but at high cost. ${ }^{60}$ Consequently, Manila's governor Curucelaegui y Arriola was ordered "to arrange the purchase in China of up to 30 quintals of mercury and to remit them to the viceroy of New Spain." It wasn't until 1692 that Fausto Cruzat y Góngora, governor of the islands, procured a small amount (1.5 quintals) for testing in the Mexican mines of Guanajuato, which equaled "the best results of [mercury] from the mines of Almaden and were better than the purist from Peru." ${ }^{\text {1 } 1}$ This was followed by using a portion of a 12,000 peso earmark from New Spain to purchase over 112 quintals at a cost of about 63 pesos each by 1695 (compared to 100 pesos for Peruvian quicksilver), with more deliveries promised in the future. ${ }^{62}$ Two years later when Gemelli Carreri visited New Spain coming from Manila, he mentioned

57. AGI Filipinas 339, L. 2, f. 10r-10v (6/1/1591).

58. AGI Mexico 26, N. 69 (10/28/1605).

59. AGI Mexico 35, N. 47 (2/21/1644).

60. AGI Filipinas 28, N. 153 (3/28/1689); 212, N. 1 (1692-1694); Lang, "New Spain's Mining Depression":637.

61. AGI Filipinas 331, L. 9, f. 71v-74r (2/8/1693); 15, R. 1, N. 43 (6/5/1695).

62. AGI Filipinas 15, R. 1, N. 8 (12/1/1692); R. 1, N. 43 (6/5/1695); 17, R. 1, N. 25 (6/3/1698). 
that the price of Peruvian and Castilian mercury ranged between 84 and 300 pesos, depending on supply, and attributed its high price to royal taxes on importation (10\%), local production (20\%), in addition to other viceregal duties. Carerri remarked that "it is the lack of quicksilver which impoverishes Mexico," a clever remark considering that he had sold some Chinese mercury in New Spain at 300 percent above its purchase price. ${ }^{63}$

Based on the evidence presented above, it would appear that Chinese quicksilver was frequently delivered to Acapulco in amounts that had a beneficial yet meager impact on New Spain's silver refining capacity. Counterintuitively, where Chinese imports contributed the most to the domestic mining industry was in provisioning workers with cotton fabrics. Juan Grau y Malfalcon mentioned " $[w]$ here it is true, and where it ought to be considered, is in the mines - where the aviadors do not and cannot use the cloth from Castilla because of its quality and value; but that of China, as it is cheaper and more durable and serviceable. Consequently, with one thousand pesos' worth of it they maintained their mining operations longer than they could with five thousand worth of that from España. From that it follows that if it [the supply of Chinese cotton stuffs] were to fail, the mines would necessarily decrease; and that would redound to the greater damage of the royal treasury, and to that of the country, your vassals, and commerce than what is suffered today, even though what is stated is considered to be accurate and true." ${ }^{4}$

\section{Textiles}

Among all the products transported from the Philippines, Asian fabrics had the most appreciable impact on New Spain's economy. From the time Manila was conquered in 1571, it was crystal clear to Spanish conquistadors and clergy in the Philippines that the only method to finance imperial endeavors in Asia was by selling Chinese silks and other products in the New World. To quote from Juan Grau y Malfalcon's detailed 1637 memorial, “The trade of the Filipinas is so necessary today in Nueva España, that the latter country finds it as difficult as do the islands to get along without that trade." ${ }^{65} \mathrm{He}$

63. Carreri, Viaje a la Nueva España, 1:140.

64. Blair and Robertson, The Philippine Islands, 27: 202-203.

65. Ibid., 198. 
goes on to list a cornucopia of Chinese textiles sold at the Acapulco Fair, but distills the bulk of exports down to unfinished or raw silk and cotton fabrics.

Unfinished Chinese silks were woven into everything from the robes worn by clerics to veils and headdresses adorning the ladies of the colony. Although vast quantities of Spanish silks were shipped from Cadíz and other Spanish ports to Veracruz annually, they were too oily, resulting in more labor and expense for those who dyed them. Likewise, a small amount of silk produced locally in Mixteca (Oaxaca) was viewed as an inferior product. ${ }^{66}$ Chinese silks, on the other hand, were not only less expensive, but the ease of dying and beauty of the whites was unmatched. ${ }^{67}$ Understandably the colonial textile industry was heavily dependent upon this commerce. As Grau y Malfalcon validated that "[f]rom the skeined silk, and the silk thread, and trama (a type of weaving silk) are manufactured in New Spain velvets, veils, headdresses, passementaries, and many taffetas... By this trade, more than 14,000 person support themselves in Mexico [City], La Puebla, and Antequerra, by their looms, the whole thing being approved by royal decrees." 68

Cotton fabrics, known colloquially as "elephant stuffs," were equally prized for their low cost and durability. In addition to cottons from India, those from China and the Philippines formed together a substantial Asian commodity that facilitated import-substitution enterprises in New Spain. In the words of Grau y Malfalcon "[o]f the cotton textiles linens are used in New Spain more than any other stuff, as they are so cheap that they sell for one and one-half or two reals per vara. They are desired by the Indians and Negroes; and when these are lacking, even though there should be an over-supply of linens of Europa, they do not want or use them, as those are dear and not so much used by the; and they get along with their own clothes from Campeche or La Gausteca, and others that they weave." 69 Writing almost a century later, the imitation of Asian fabrics in New Spain was a well-established industry. Antonio Álvarez de Abreu related in 1736 that the elephant stuffs and raw silk woven in Puebla and Mexico City "which comes from the Philippines... is worked up, and in this industry many poor persons are employed."70 Alexander von Humboldt underscored that point in the last quarter of the eighteenth

66. Ibid., 199.

67. Ibid., 45: 46-47.

68. Ibid., 27: 199.

69. Ibid.,199-200.

70. Ibid.,45: 37. 
century when discussing the importance of cotton weaving (especially mantas and rebozos) in Puebla, Huexocingco, Tlaxcala, and Queretaro. He observed that "[i]n this town [Puebla] as well in Mexico [City], the printing of calicoes, both those imported from Manila, and those manufactured in New Spain, has made considerable progress." ${ }^{11}$

Aiding, abetting, and profiting from Asian textiles were master silk weavers from Toledo, Granada, Torrijos and other cities in Castile that migrated to Mexico City and established obrajes and trapiches to dye, finish, and sell Chinese silks domestically or export them to the mother country. Grau y Malfalcon described how the silk industry in the cities of Granada and Toledo had dramatically declined after 1618 (owing to cheaper imports of Chinese silk sold illicitly by the Dutch to merchants in Spain), leading to a migration of "the workmen of that trade, through lack of silk with which to work" to New Spain. ${ }^{72}$ Hoberman's superb study of merchants in the capital illustrates this phenomenon in the early seventeenth century. Peninsulares such as Juan de Castellete, Fernando de Padilla, Francisco de Esquivel Castañeda, Francisco Sánchez Cuenca, and Pedro de Brizuela imported raw silks and thread from Manila, spun, wove, and/or dyed their products and sold them domestically or re-exported them to Spain via Veracruz. ${ }^{73}$ Manufacturers catered to what was fashionable and thus were heavily influenced by Oriental patterns and designs. For example, the rebozos that women of viceroyalty desired had to be embroidered in the Chinese style, but blended with Mexican motifs such as bullfights, pastoral scenes, or the promenade of carriages that was en vogue for elites in Mexico City. ${ }^{74}$ As trade relations intensified, Castilian and criollo merchants traveled to Manila with samples of clothing patterns that were in high demand by affluent subjects in the king's American colonies. According to a source in the late seventeenth century, Mexican and Peruvian merchants arrived in the Philippines with specimens of Spanish fabrics, which

71. Von Humboldt, Political Essay on the Kingdom of New Spain, 3: 461-462.

72. Blair and Robertson, The Philippine Islands, 27: 202.

73. Louisa Schell Hoberman, Mexico's Merchant Elite, 1590-1660: Silver, State, and Society (Durham: Duke University Press, 1991), 129-131.

74. Manuel Carballo, "Influencia Asiática," in Fomento Cultural Banamex, ed., El Mueble Mexicano: Historia, Evolución e Influencias (Mexico City: Fomento Cultural Banamex, 1985), 122. 
were conveyed by Sangleys in the Parián to factories in various cities along China's coast. ${ }^{75}$

How detrimental were Chinese silks to Mexico's domestic sericulture industry? Much has been made about this link between the ascendance of the former and the decadence of the latter. Humboldt places the blame squarely on two agents provocateurs: the Council of Indies (legislating a suppression of the industry on behalf of peninsular merchants) and China's most lucrative import. ${ }^{76}$ Recent scholarship on Mexico's silk industry rebuts his initial claim but confirms the negative influence of Acapulco's commerce with Asia. A domestic silk industry prospered in New Spain following the conquest by Cortez. Blessed with an ideal climate for sericulture (specifically in the regions of Oaxaca and Puebla), Mexico's silk-rearing and manufacturing industries prospered in the second and third quarters of the sixteenth century. ${ }^{77}$ Nevertheless, it began an unstoppable descent by the mid-1570s as the result of several interrelated factors: a series of devastating plagues (1575-1592) that killed off approximately one-half of the Indian population; survivors that channeled their energies afterwards on food crops; and clergy who viewed silk-rearing as "harmful to the spiritual well-being of the Indians" due to the slave-like nature of the industry. ${ }^{78}$ Chinese silk did not kill native sericulture, but the serendipitous circumstances of cheaper, well-made Asian fabrics flowing into New Spain after the conquest of Manila, coupled with Spanish imports, doubtlessly de-incentivized its production.

75. Blair and Robertson, The Philippine Islands, 45: 64. Apparently this venture was successful, for Antonio Álavrez de Abreu complained in 1736 that "imitations of all the satins, velvets, ribbons, mantles, hose, and every kind of silks which were manufactured in España; [and these were] so showy and beautiful that, not only for this reason but on account of the very moderate prices at which they were sold throughout Nueva España, no other kind of silks were used than those of China" (44: 255). Despite some exaggeration on his part (he was anti-Asian trade), Álvarez de Abreu confirms that Castilian patterns were manufactured by Chinese weavers.

76. Von Humboldt, Political Essay on the Kingdom of New Spain, 3:57-58.

77. Joaquín García Izcazbalceta, "La Industria de la Seda en México" in Joaquín García Izacazbalceta, ed., Biografías y Estudios (Mexico City: Editorial Porrúa, 1998), 337-347; Teresa de Maria y Campos and Teresa Castelló Yturbide, eds., Historia y Arte de la Seda en Mexico, Siglos XVI-XX (Mexico City: Fomento Cultural Banamex, A.C., 1990), 34-60.

78. García, "La Industria de la Seda en México," 346-349; Maria and Yturibide, Historia y Arte de la Seda en Mexico, 60-66. 


\section{Ceramics}

Following the capture of Manila by conquistadors, an increasing number of trade junks were drawn to Lusong (Luzon) by the glittering tons of silver transported aboard galleons from New Spain and Peru used to purchase Oriental exotica. Pedro Chirino confirmed as much in 1602, writing that "[f]rom China they... began to ship their riches in silks and glazed earthenware, as soon as they learned of our wealth of four and eight real pieces."79 Porcelains were shipped to Manila from the famous Jingdezhen kilns in Jiangxi, the Dehua kilns in Fujian, the workshops catering to Europeans in Canton, and smaller facilities in Chaozhou (Swatow) and Zhejiang province. ${ }^{80}$ In 1573, when the first two Manila galleons arrived in Acapulco with a cargo that included over 22,000 Ming dynasty porcelains, a market for Oriental ceramics was firmly established. ${ }^{81}$ In addition to ceramics with gold and silver plating, Chinese porcelains of the qingbai (blue and white) style were extremely popular in the haciendas of elites and the Catholic sanctuaries of New Spain. Some elites went as far as to special order armorial plates in Canton bearing their family crest with writing in the Spanish language meticulously copied. ${ }^{82}$

The Manila porcelain trade stimulated an import-substitution pottery industry in the city of Puebla, which slavishly imitated the Ming and Qing dynasty styles and motifs that were the all the rage in Europe. Blessed with deep and wide-ranging clay strata of various types, Puebla de Los Angeles became the most heralded manufacturing center of Spanish colonial ceramics in the early seventeenth century, supplanting Mexico City's San Juan barrio in the process. Master potters from Spain founded kilns in Puebla during the late 1500 s that mass produced a variety of items, notably white glazed maiolica (loza blanca) earthenware fabricated in the Talavera style, named after the kilns in Talavera de la Reina. ${ }^{83}$

79. Blair and Robertson, The Philippine Islands, 12:191.

80. George Kuwayama, Chinese Ceramics in Colonial Mexico (Honolulu: University of Hawaii Press, 1997), 15.

81. Ibid., 11.

82. John Goldsmith Phillips, China Trade Porcelain: An Account of its Historical Background, Manufacture, and Decoration (Cambridge, Mass: Harvard University Press, 1956), 54-57; Kuwayama, Chinese Ceramics in Colonial Mexico, 52.

83. Margaret Conners McQuade, Talavera Poblana: Four Centuries of Mexican Ceramic Tradition (New York: The Americas Society, 1999), 13-20; Gauvin Alexander Bailey, "Asia in the Arts of Colonial Latin America" in Joseph J. Rishel and Suzanne Stratton-Pruitt, eds., The Arts of 
China's qingbai porcelains, which were copied and referred to as Talavera Poblana following Mexico's independence from Spain, became more pronounced in the second quarter of the seventeenth century (as were those modeled after Japanese imari style). ${ }^{84}$ In 1653 , a potters' guild was officially sanctioned in the city. The revised guild regulations of 1682 stipulated that "[i]n making fine wares the coloring should be in imitation of Chinese ware, very blue, finished in the same style and with relief work in blue, and on this pottery there should be painted black dots and grounds in colors." 85 Chinese figures, designs, and motifs were incorporated in a wide variety of earthenware, including servants with queues, phoenixes, pagodas, clouds in the rui scroll pattern, rocks and gardens, birds (cranes and phoenixes), and flowers (chrysanthemums and peonies). ${ }^{86}$

The myriad of Chinese-influenced shapes imitated by Pueblan craftsmen was also quite substantial. Potters' configurations of jars (including those with metal covers), cups, hemispherical bowls with foot-rings, and pear- and gourd-shaped bottles clearly indicate the Orientalization of Talavera Poblana. ${ }^{87}$ Chinese "Fu Dogs," or perros de Fo, lion/dog statues that guarded the entrance to temples and palaces in the Middle Kingdom, were miniaturized and adapted as ceramic candle stick holders by Pueblan artisans. ${ }^{88}$ The paradigm shift towards Asian styles, themes and forms was accelerated by the annual arrival of hundreds of chino slaves and freemen, including those with ceramic-making experience, who trekked along the royal highways to Mexico City and Puebla. Chinese and mestizo potters from Manila, and perhaps a few Japanese, manufactured fine Talavera porcelain from which Mexican ceramics achieved respectability and fame. ${ }^{89}$ The ceramic tiles that embellished churches with biblical scenes and saintly images, or the kitchens of numerous homes with

Latin America, 1492-1820 (New Haven: Yale University Press, 2006), 99-101, 107; Florence C. Lister and Robert H. Lister, Sixteenth Century Maiolica Pottery in the Valley of Mexico (Tuscon: University of Arizona Press, 1982), 4.

84. Rishel and Stratton-Pruitt, eds., The Arts in Latin America, 99-100.

85. Efraín Castro Morales, "Puebla y la Talavera a través de los siglos" Ártes de Mexico 3 (2002): 24, 71; Kuwayama, Chinese Porcelains in Colonial Mexico, 24.

86. Kuwayama, Chinese Porcelains in Colonial Mexico, 25; Rishel and Stratton-Pruitt, eds., The Arts in Latin America, 100.

87. Kuwayama, Chinese Ceramics in Colonial Mexico, 25, 34-35, 49, 75, 77, 78, 82.

88. Carballo, "Influencia Asiática", 126.

89. Virginia Armella de Aspe, "Artes asiáticas y novohispanas" in Fernando Benítez et al, El Galeón del Pacífico: Acapulco-Manila, 1565-1815 (Mexico City: Bilioteca del Sur, 1992), 236. 
secular themes, incorporated the Oriental with Iberian and native Indian, creating a unique hybrid catering to consumer tastes in New Spain..$^{90}$ Elites who drank hot cacao in their mancineras of Chinese or Mexican manufacture literally imbibed the blending of cultures produced by Orientalization. ${ }^{91}$

Furniture and Lacquerwork

The popularity of fine Asian art among the ruling classes in New Spain stimulated a flourishing import substitution business for domestic craftsmen specializing in home furnishings. Among the items transported by the Manila galleons were Chinese and Japanese lacquered wooden windbreaks or folding screens, called pingfeng or pingzhang in Cathay, featuring a minimum of four panels to as many as twelve. An elite household decoration since at least the Han dynasty (202 B.C. - 220 A.D.), the scenes on the panels normally portrayed natural (Daoist) themes such as mountains, rivers, birds, animals, trees, flowers, pagodas, the four seasons, calligraphy or human activity in upperclass mansions or the imperial palace. ${ }^{92}$ Various methods of construction were employed, including gold, silver, vermillion and black lacquers, inlaid with bone, ivory, or mother-of-pearl. During the Tang dynasty (618-907 A.D.), when Japan underwent an intense period of Chinese cultural borrowing, the pingfeng were widely imitated and called byobu (the Nipponese pronunciation of the Chinese characters pingfeng). ${ }^{93}$ When the Portuguese and Spaniards began trading and evangelizing in Japan after the 1550s, local craftsmen catered to their foreign buyers by painting Iberians into the panel scenery, thereby creating the namban byobu (Southern Ocean Barbarian windbreaks). 94 This cultural syncretism between East and West preserved on lacquered panels would not be confined to Japan alone, but it would ultimately undergo another transformative experience in Mexico.

When Tokugawa Ieyasu sent five black lacquer and gilded byobus as presents to the viceroy of New Spain in 1613-14, the aesthetic beauty of

90. Mitchell A. Codding, “The Decorative Arts in Latin America, 1492-1820”, in Joseph J. Rishel and Suzanne Stratton-Pruitt, eds., The Arts in Latin America, 1492-1820 (New Haven: Yale University Press), 100-101.

91. David B. Warren, "The Arts of Viceregal Mexico, 1521-1821: A Confluence of Cultures" Antiques 161.4 (April 2002):123-124; Kuwayama, Chinese Ceramics in Colonial Mexico, 74.

92. Michel Beurdeley, Chinese Furniture translated by Kathering Wilson (New York: Harper \& Row Publishers, 1979), 16-28.

93. Beurdeley, Chinese Furniture, 23-27, 112-142; Castelló and Martínez, Biombos Mexicanos, 11.

94. Castelló and Martínez, Biombos Mexicanos, 12; Coddell, "The Decorative Arts in Latin America," 104-105. 
the artwork - as well as its utility for creating elegantly private space - was immediately appreciated by the New World nobility. ${ }^{95}$ Japanese artisans who had accompanied the delegation began manufacturing biombos (the Spanish corruption of byobu) in Puebla and Mexico City shortly thereafter, passing down the intricate manufacturing methods to local craftsmen. ${ }^{96}$ Aside from biombos constructed entirely of wood, the interior painted panels were also made of linen and paper, and were prominent display pieces in the salónes de estrado (parlor rooms) of opulent haciendas and palaces. ${ }^{97}$ Grand colonial mansions had many rooms which led to enormous open-air patios, and therefore the biombos not only offered protection from the wind, but served as a portable adornment for any social occasion. For example, when the Marqués de Villena arrived in the Castle of Chapultepec prior to assuming his official duties as viceroy in 1640, it was recorded that "At the far end [of his dining room] there were two exquisite Chinese screens to shield the musicians from view. The music had been ordered to accompany His Excellency while dining." 98

Folding screens came in many shapes and sizes, from the taller biombos de cama (placed at the foot of the bed to create a more intimate space) to the shorter biombos de rodastrado (with more panels for enclosing the dais used to entertain guests). ${ }^{99}$ The Franz Mayer Museum in Mexico City contains a 10-panel biombo portraying the conquest of Mexico by Cortez on one side, and a map of the capital on the other. Meticulously fabricated with a wooden frame and canvas panels in the late seventeenth century, this magnificent relic dramatically reflects the confluence of Oriental, Iberian, and native Indian cultures in the viceroyalty. ${ }^{100}$

95. Nuttall, "The Earliest Historical Relations between Mexico and Japan (From Original Documents Preserved in Spain and Japan)" American Archaeology and Ethonology 4.1 (April 1906), 35;Castelló and Martínez, Biombos Mexicanos, 27. This last source states that the number of gilded byobu was actually ten.

96. Manuel Carballo, "Influencia Asiática" in El Mueble Mexicano: Historia, Evolución e Influencias, edited by Carmen Aguilera (Mexico City: Fomento Cultural Banamex, 122.

97. Warren, "The Arts of Viceregal Mexico", 123-125;Carballo, "Influencia Asiática", 122.

98. Gustavo Curiel, "Rituals among the Elites of New Spain: The Evidence from Material Culture" in Héctor Rivero Borrell et al, The Grandeur of Viceregal Mexico Treasures from the Museo Franz Mayer (Mexico City and Houston: The Museo Franz Mayer and The Museum of Fine Arts, 2002), 33.

99. Castelló and Martínez, Biombos Mexicanos, 12-25. Rodastrado literally means "encircling the estado (dais)".

100. Héctor Rivero Borrell, et al., ed., The Grandeur of Viceregal Mexico: Treasures from the Museo Franz Mayer (Mexico City: Museo Franz Mayer and The Houston Museum of FineArts, 2003), 83-87. 
A large inventory of lacquered Asian household goods was transported across the Pacific to Acapulco and imitated by local and immigrant chino cra$\mathrm{ftsmen}$. In addition to biombos, the most popular pieces were headboards, chests, boxes, wardrobes, sewing boxes, and writing desks, while serving trays, cups and gourd bowls were comparably decorated. ${ }^{101}$ Pre-Hispanic techniques of lacquering later known as laca (lacquer), barniz (varnish) or maque (derived from the Japanese word maki-e that incorporated silver and gold into the finish) were applied to a variety of wooden objects, and production facilities proliferated the colonial era. ${ }^{102}$ Using oils from cochineal, chia and chicolate seeds, mixed with various mineral clays and organic pigments, Mexican lacquer artisans created masterful works in the cities of Pátzcuaro, Peribán, Quiroga and Uruapan in Michoacán, and Olinalá in Guerrero, among other places of lesser note. ${ }^{103}$ Of all its competitors, "Pátzcuaro... gained renown in the eighteenth century for its Asian-inspired lacquerwares." 104 The most celebrated lacquer master in Pátzcuaro was José Manuel de la Cerda, whose masterpieces were said to have surpassed those of Asian origin: "Pieces from his workshop show the most pronounced Asian influence, with landscapes of weeping willows, flowering plums, cranes, pagodas and other structures of a general Asian style, set against a ground of black lacquer." ${ }^{105}$ Imitation being the sincerest form of flattery, Mexican artisans imported a vermillion powder from China known as "rojo chino" to achieve the authentic Oriental spirit of their wares. ${ }^{106}$

\section{Conclusion}

The Orientalization of New Spain is in no way to be conflated with Edward Said's concept of "Orientalism" for several compelling reasons. The Orient

101. Armella de Aspe, “Artes asiáticas y novohispanas", 238-239; Carballo, "Influencia Asiática",138-139; Coddling, "The Decorative Arts in Latin America", 110.

102. Isabel Medina González, "Pre-Hispanic Lacquerwork: A Long-Standing Debate," in Ruth Lechuga et al, Lacas Mexicanas (Mexico City: Museo Franz Mayer and Artes de Mexico, 2003), 68-70; Codding, "The Decorative Arts in Latin America," 109.

103. Sonia Pérez Carrillo and Carmen Rodríguez de Tembleque, "Oriental and European Influences" in Lechuga et al, Lacas Mexicanas, 70-73; Carballo, "Influencia Asiática", 130-131; Codding, "The Decorative Arts in Latin America", 111-112.

104. Codding, "The Decorative Arts in Latin America", 111.

105. Ibid., 111-112.

106. Carballo, "Influencia Asiática",132. 
or "la China" in colonial Mexico, generally speaking, is China, Japan, the Philippines and the rest of Southeast Asia plus India, exclusive of Arabian, Islamic or Middle Eastern cultures (the Near East) that encompass North Africa, the Arabian Peninsula, Turkey, Iraq, Iran, Pakistan and Afghanistan, the regions constituting Said's 'Orient'. Chronologically speaking, Said's Orientalism starts to emerge in the late eighteenth century at precisely the time when Orientalization was declining in the Americas. ${ }^{107}$ Moreover, the Eurocentric sense of "otherness" for Asia that is expressed as cultural or technological inferiority and foreign/exotic/remote populations and lands, is, for the most part, nonexistent in the history of New Spain. To the contrary, the blending of cultures and traditions, a willing acceptance or tolerance of Asian people and products that constituted the process of Orientalization in colonial Mexico stands in stark contrast to the historical experiences of European nations during the same time frame.

One example of this distinction would be the manufacture of Oriental wares (textiles and porcelain) in New Spain. The first-hand transfer of skills and techniques by chino craftsmen to other castas and Iberians working together in the guilds, obrajes, and factories was a common scene in the seventeenth century. European import-substitution industries in Holland (Delft) or England (Wedgewood-type of products), on the other hand, operated in comparative isolation half-a-world away from their source of inspiration. That cultural and physical distance from Asian artisans and their expertise that existed in the minds of Dutch and Anglo-Saxon potters was similarly chronicled by various Europeans who lived or traveled in New Spain. Taking chronological samples from manuscripts penned by the Irishman Thomas Gage (1620s), the Italian Gemelli Carreri (1697), and the Prussian Alexander von Humboldt (1800), each of them expressed surprise, bewilderment, or a sense of extraordinariness to encountering sizable numbers of Asians in colonial Mexico. ${ }^{108}$ For those born in New Spain, however, Asian people were part of everyday, normal, mundane life, and therefore not viewed as something foreign or exotic - they were just chinos. Gage, Carreri and Hum-

107. Edward W. Said, Orientalism: Twenty-fifth Anniversary Edition (New York: Vintage Press, 2003), 1-3.

108. Thomas Gage, A New Survey of the West Indies, 1648 (New York: Robert M. McBride \& Co., 1929), 84; Carreri, Viaje a la Nueva España, 1:102-103; von Humboldt, Political Essay on the Kingdom of New Spain, 1:130. The dates placed next to the authors' names indicate the years they were actually in New Spain. 
boldt fit the mold of the social scientists and colonial administrators whom Said attributes the creation of the "Oriental" for Europeans. They are cold, distant observers, not active participants; there is no respect/appreciation for, nor willing integration with the cultural environment of the viceroyalty.

One last point I would like to make on this subject is how the Asian or chino/a underwent a startling metamorphosis in Mexico over the span of three centuries. As I have documented in previous articles, from 1565 until the 1690s the term was unambiguous in defining chinos as people coming from South, Southeast, and East Asia. Around the time of the Mexico City riot (1692), nonetheless, it starts to be applied to mulattoes who are Asianlooking. By the time casta portraits appear in the mid- to late 1700 s, the chino/a is viewed as a person of mixed Indian and African blood. ${ }^{109}$ Following the Mexican War of Independence, the word china became widely accepted to mean a pure-blooded india temptress from the pueblos of the countryside, and a national icon. ${ }^{110}$ To reiterate, the embracing of Asians as one of their own to the point of the term china losing all connection to lands across the Pacific Ocean is truly astounding. Said's "Oriental", conversely, would never be accepted or culturally internalized in Europe.

Acclimation to the socio-cultural environment of New Spain was not - comparatively speaking - as psychologically disruptive for Asian immigrants owing to the evolution of an Oriental support system that I call the 'chino network.' When one considers the stories of the Pampangan muleteer Domingo de Villalobos in Tzapotlán, or the Japanese businessman Juan de Páez in Guadalajara, they are microcosmic portraits of a much larger phenomenon in colonial Mexican society. ${ }^{111}$ During three centuries of Spanish rule it is essential to comprehend that during eighty percent of that epoch a constant flow of sailors, merchants, craftsmen, slaves, and servants from sundry nations of South, Southeast, and East Asia were able to encounter their countrymen rather easily along the west coast and especially the large urban centers of Mexico City, Puebla, and Guadalajara.

109. Edward R. Slack, Jr., "The Chinos in New Spain: A Corrective Lens for a Distorted Image" Journal of World History 20.1 (March 2009):57-67; "Sinifying New Spain: Cathay's Influence on Colonial Mexico via the Nao de China" Journal of Chinese Overseas 5.1 (May 2009): 20-24.

110. Gutierre Tibón, "The Two Chinas" Artes de Mexico 66.1 (2003): 66-69.

111. See the pioneering scholarship by Melba Falck and Héctor Palacios in El japonés que conquistó Guadalajara:La historia de Juan de Páez en la Guadalajara del siglo XVII (Guadalajara: Universidad de Guadalajara, 2009). 
As a counterpoint to the stories of Villalobos and Páez, there is Jonathan Spence's book The Question of $\mathrm{Hu}$, the story of a man from southern China converted by French Jesuits and taken to Europe in the 1720s. From the moment John Hu's boat departed Canton in January 1722 he began to experience isolation, fear, and separation anxiety that become even more intense over the eight months' journey via the Indian and Atlantic oceans to Port Louis. After approximately eight more months of living in France, John Hu was forcibly taken away from his abode and locked up in an insane asylum for two and one-half years, merely for exhibiting behavior that one could diagnose as a severe case of culture shock. ${ }^{112}$ Such a nightmarish encounter would never have occurred had John Hu travelled across the Pacific from Canton/Manila to New Spain. To begin with, the Philippine capital was teeming with Chinese from Fujian and Guangdong provinces who spoke a variety of dialects. For the six month's voyage aboard the "China ship" he would have found a crew that was over 70\% Asian, and most likely a fellow Chinese or Chinese mestizo who could speak his native tongue. Once in Acapulco, $\mathrm{Hu}$ would have immediately plugged into an extensive 'chino network' that would have smoothed his cultural transition to life in the viceroyalty.

When one comprehends the Oriental inspiration for Talavera Poblana pottery, the fusion of Castilian, Mexican, and Asian cultures in the biombo from the Franz Meyer museum, the reja de coro in the Cathedral of Mexico City, early Mexican saints of the seventeenth century such as San Felipe de Jesús (a creole martyred in Japan) and Caterina de San Juan (a slave from Mughal India), the Philippine alcoholic beverage tuba distilled in Jalisco, and two and one-half centuries of virtually uninterrupted chino migration to New Spain - all of this evidence indicates a multifaceted connection to Asia that was intense, durable, and transformational. Nothing comparable exists in the history of early modern Europe, which is why Said's Orientalism has a disturbing ring of truth for the Occident, yet remains eerily silent to explain the process of Orientalization that heavily influenced the viceroyalty of New Spain. mp

112. Jonathan Spence, The Question of Hu (New York: Vintage Books, 1989). 


\section{Observación internacional de elecciones y soberanía}

Observación internacional de elecciones soberanía y la Idea del Hemisferio Occidental El surgimiento de una norma internacional

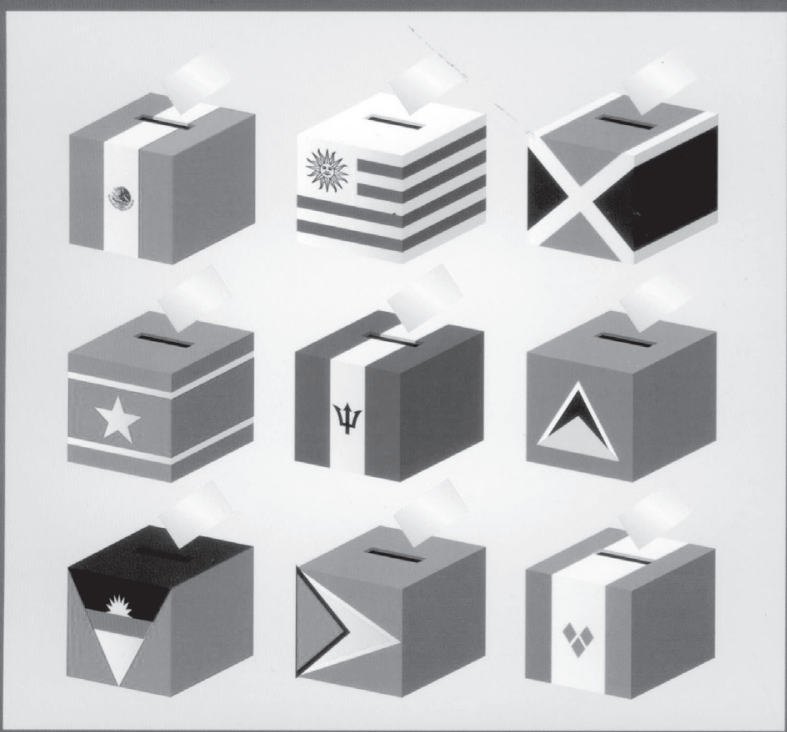

\section{Arturo Santa Cruz}

UNIVERSIDAD DE GUADALAJARA 